University of Nebraska - Lincoln

DigitalCommons@University of Nebraska - Lincoln

To Improve the Academy

Professional and Organizational Development Network in Higher Education

1994

Valuing the Student Voice: Student Observer/Consultant

Programs

D. Lynn Sorenson

Follow this and additional works at: https://digitalcommons.unl.edu/podimproveacad

Part of the Higher Education Administration Commons

Sorenson, D. Lynn, "Valuing the Student Voice: Student Observer/Consultant Programs" (1994). To Improve the Academy. 325.

https://digitalcommons.unl.edu/podimproveacad/325

This Article is brought to you for free and open access by the Professional and Organizational Development Network in Higher Education at DigitalCommons@University of Nebraska - Lincoln. It has been accepted for inclusion in To Improve the Academy by an authorized administrator of DigitalCommons@University of Nebraska - Lincoln. 


\section{Valuing the Student Voice: Student Observer/Consultant}

Programs

\section{Lynn Sorenson}

Brigham Young University

This article discusses student observer/consultant programs which train impartial students who are invited to give feedback to faculty participants on their teaching. These programs are one way to value the student voice in faculty development. An overview and brief analysis of student observer/consultant programs and evaluations by participants are provided.

At the 18th Annual POD conference "Unveiling Inherent Values," Kenneth Zahorski of St. Norbert College (WI) encouraged "involving students in faculty development [as] a matter of value and values." He reminded us that "in the last two decades ... we have moved from a teaching-centered enterprise to a learning-centered profession, from teacher-centered courses to student-centered classrooms." In citing "student-centered pedagogies, the empowerment of students, learning partnerships, and the student as ultimate beneficiary of faculty development," Zahorski implored faculty developers to "make sure the rhetoric actually reflects reality"(1993).

There are a number of examples where the student voice is valued in faculty development. Probably the most well-known examples of student input for instructional development are the Classroom Assessment Techniques (Angelo \& Cross, 1993). In another instance, Bette Lasere Erickson has assembled panels with students of color for 
faculty training sessions on diversity at the University of Rhode Island. At Brigham Young University, Donald Jarvis has responded to a student plea for more opportunity to make informed choices regarding courses and instructors at registration time. Jarvis is working with student government leaders to develop a computer-accessible directory of courses and professors, their teaching philosophies and methods in order for students to match their learning styles with professors' teaching styles. At St. Norbert, Zahorski has formed, among other things, faculty development committees which include students. And, the focus of this article, a number of campuses have implemented student observer (or consultant) programs, as a method of gathering data about the teaching and learning environment. Student observer/consultant programs offer yet another perspective for faculty introspection, discussion, and, we hope, teaching and learning improvement.

Classroom student observer/consultant programs are a unique way for college teachers to receive feedback on their teaching from the impartial student view. A trained student who is not a member of the class is invited by an instructor to gather data on teaching and learning in a particular course. As the Carleton College Guidelines for Student Observers (1993) explains, the purpose of a classroom student observer program is to provide confidential observations/feedback in order to enhance an instructor's effectiveness in helping students learn. Listening to this student voice allows faculty members to gain a broader perspective on their teaching and their students' learning. One faculty participant commented that the student observer "provides another valuable 'set of eyes' to see what's going on. Teachers don't often know what's getting through (especially in a large class) nor [do they know] some of their bothersome mannerisms that may hinder effective teaching" (Sorenson, 1993b).

\section{A Brief Overview of Student Observer/Consultant Programs}

An historical survey of student observer programs reveals an early observation in 1971 of University of Chicago Professor Brian J. L. Berry by an impartial student, L. Dee Fink, for the purpose of teaching 
improvement (Fink, 1973). However, observations of this sort did not develop into full-fledged programs until the mid-seventies when a pioneer student observer program was organized at Carleton College (MN). In 1976, inspired by the neighboring Carleton program and spurred on by a Danforth Fellowship, Barbara Helling, St. Olaf College (MN) professor of psychology, established a student consultant program which she still directs (Sorenson, 1993a). The Brigham Young University (UT) Classroom Student Observer Program (CSOP) which I coordinate was originated by Professor Thomas DeLong who in 1990 initiated an honors course on teaching and learning, a component of which was observation of college classes. I "inherited" this program in 1992.

Institutions known to support other student observer programs include Miami University $(\mathrm{OH})$, the University of Chicago, and the University of Georgia. Besides Helling and myself, other POD members coordinate student observer programs at Carleton and Rutgers (NJ); this article focuses on the BYU, Carleton, and St. Olaf programs. Although each student observer/consultant program has its own distinct characteristics, the three programs highlighted here have a number of major commonalities: faculty self-selection by invitation, methods of student observer selection, and training for student observers. As I discuss these commonalities, I will also emphasize the unique features of the BYU Classroom Student Observer Program.

\section{Faculty Self-Selection by Invitation}

Faculty members are invited by program coordinators to participate in the programs. Typical participants are professors well known for their excellent teaching (good teachers who want to get even better), new instructors, faculty members teaching new courses or experimenting with changes in old ones, and a very small percentage of instructors who have major problems with teaching and/or relating to students. When BYU faculty members request an observer, they receive the Faculty Handbook (Sorenson, 1994a) detailing the program's philosophy and procedures. 


\section{Selection of Student Observers}

Student observers/consultants are recommended from honors programs, schools of education, student governments, service organizations, and/or are referred by professors who note students with particular interest in the teaching and learning enterprise. Student observers should be successful students themselves and, at BYU, must submit recommendations from two professors. Many student observers participate semester after semester. It should be noted that students are assigned only as professors make requests for classroom observation. Observers are paid through work-study and/or at campus student wages. However, it does not appear that receiving pay is a necessity in establishing a student observer/consultant program. In fact, students at BYU have often volunteered for the program and been surprised to discover they would be paid. An alternative to monetary remuneration would be offering credit for observation; or, student participation could be solely a service.

\section{Training Student Observers}

Student observers are trained by campus faculty developers at regular meetings, in classes about teaching and learning, and/or in presemester workshops. The training includes interpersonal communication skills, observation techniques, and report writing. Students enrolled in classes about teaching and learning receive an introduction to instructional theory and techniques. They become acquainted with ideas of Bloom, Kolb, Light, Palmer, Tobias, and others. During their training, student observers receive handbooks, observation forms, readings, and other materials which help them prepare for their observation responsibilities. At BYU, all new observers perform a practice visit to one of three volunteer "guinea pig" professors (from management, microbiology, or Russian language) and write up an observation before they receive their first official assignment. The purpose of this visit is to help them feel more comfortable and confident in their observation skills.

Strict confidentiality is maintained. A good deal of time is spent emphasizing to students the confidential nature of the observer/instructor relationship. However, some faculty participants pleased with 
their student observer experiences speak publicly about its benefits and recruit both colleagues and students to take part.

"Sensitive to the ways of academe and the tides of human nature" (Rhem, 1993), program coordinators take great pains to assure that student observers keep two things clearly in mind:

1. They are in the classroom at the instructor's invitation. [BYU calls its program "professor-driven."]

2. They fully understand the difference between observation and opinion. (Rhem, 1993)

Students do not offer opinions - not even positive critiques - unless specifically invited. There is a natural tendency to form opinions, to become critics. Student observers are trained instead to be "mirrors" so that faculty members can become their own classroom critics. Helling's experience has taught her that observers will be asked for their opinions and will serve as student consultants to the professor participants. She trains the St. Olaf observers/consultants to be "specific so that there is some concrete information, selective so that there is some guidance as to appropriate directions for effort, and positive so that there is some encouragement" (Helling, 1988).

During their training, student observers become well acquainted with their campus faculty developers to whom they can refer professors' more complex questions. At BYU, instructors who have never used any Faculty Center resource often begin to use its library, independent evaluations, and so forth as a result of their contact with a student observer. In other words, while student observers may lack extensive knowledge of theory-based course design or the intricacies of overcoming gender bias in class discussion, they do know where to send faculty who want to explore wider teaching and learning issues.

Faculty members who respond to invitations to participate in student observer/consultant programs decide what sort of data they would like from their student observers. At BYU, faculty members receive a list of options from which to choose. Their student observers may serve in any of the following roles:

1. Recorder/Observer. The student observers record in writing what happened in class, focusing on how the class proceeded, not necessarily what was taught. Possible feedback includes a chrono- 
logical record of time spent on different activities - board work, questions, small group discussion, and so on.

2. Faux Student. Here the student observers take notes as though they were actual students enrolled in the class. This role emphasizes recording what was taught rather than how it was taught. From these notes faculty members may see how the cognitive presentation of material looked from the student perspective-what seemed most important, what examples were noted, and so forth.

3. Filmmaker. The students film the class and give the video tapes to the instructors. Later, depending on faculty preference, they may view and discuss the tape together.

4. Interviewer. In this model, the professors leave class fifteen minutes early, and the student observers talk with the class members. Assuring the students' confidentiality, the observers ask them to write answers to three questions which are similar to those from the Small Group Instructional Diagnosis (SGID) pioneered at the University of Washington:

What should the professor keep doing? or What helps you learn in this class?

What should the professor quit doing? or What hinders your learning in this class?

What should the professor start doing? or What suggestions do you have for improving the class?

The observer forms small groups of students for discussion and then reassembles the whole group to find consensus. Later the observer provides a written report for the instructor.

5. Primed Student. Here the professors tell the student observers what to look for. Instead of recording everything, the observers concentrate on something specific, suck as involvment of students in discussion, clarity in the working of problems, or meaningful closure.

6. Student Consultant. This model implies an on-going series of observations and an evolving relationship between the observed and the observers. At Carleton this is the most common model, and an observer attends all class sessions of a particular course. As both data and trust build, instructors often invite student observers to offer ideas and suggestions. 


\section{Other. Instructor choice.}

\section{Effectiveness of Student Observer/Consultant Programs}

Just as instructors need feedback, student observer/consultant programs require feedback and suggestions to improve. Participants, both faculty and students, complete evaluations at the end of each semester or module of participation. The evaluations ask about the effectiveness of options selected, various observation techniques, strengths and weaknesses of the program, and suggestions for the future. The responses have been overwhelmingly positive, and participants have found the programs valuable. A St. Olaf professor said, "We're lucky to have this program!" (Rost, 1991).

Speaking about her experience with the Classroom Student Observer Program, one BYU professor reported, "It made me more 'self-conscious' in a positive way. It clearly helped my teaching and made it more responsive to students' needs" (Sorenson, 1993b). A comment on the timeliness of the feedback came from a Carleton professor who said, "It's a fine sounding board for regular fine-tuning which I like to give courses while they are in process, not just after they are over" (Scafe, 1993).

Often professors make specific changes after receiving feedback from their observer/consultant. For example, one BYU professor reported, 'The most telling criticism I got [as a result of an observer's interview of the class members] was that my tests were unfair. The observer told me [that the interviews revealed] students didn't know what to study for on the tests and that sometimes they didn't understand the words I used to ask my questions on the tests. As a result, I now make a point of having my TAs ... double-check [tests for] their clarity and fairness" (Rhem, 1993).

Many professors commented on the competence of the student observers/consultants. One professor said, "My observer was bright, personable, and articulate. [She] gave me specific feedback about specific problems" (Sorenson, 1993b). Other comments from professors were, "[My observer] was respectful to me but not afraid to tell me exactly what he saw. This helped me see the class from another 
perspective" (Sorenson, 1993b) and "I have been reviewed by my colleagues, and I haven't had any constructive criticism from them of as high caliber as from this program!" (Rost, 1991).

As Zahorski suggested, moving from "teacher-centered courses to student-centered classrooms" involves listening to student observers' feedback about these student observer/consultant programs as well. A student observer at BYU said, "[CSOP] helped me realize that there is not necessarily 'one right teaching technique.' An instructor needs to try various ways of teaching in order to appeal to students' various ways of learning" (Sorenson, 1993b).

Student observers also benefit from their experiences in the programs. One student consultant said, "This has helped me prepare for teaching, more so than even my education classes. I can't wait to try things out in my classroom!" (Scafe, 1993). Another observer said, "I am now seriously considering going on to graduate school with the idea of becoming a professor. The 'inside view' I got [as a student observer] has influenced my future goal(s)" (Sorenson, 1993b).

Student observers appreciate the relationships which develop as they consult with faculty in these programs. They also value the opportunity to enhance teaching and learning. Student participants remarked, "The professor takes me seriously, appreciates me, and listens to what I say" (Scafe, 1993) and "The professor and I had good rapport which made me a valuable resource to him. I think the interview was the most valuable [service I performed]. The students were frank, and in the large group discussion, [they] really brought the main strengths and weaknesses of the class into sharp focus" (Sorenson, 1993b).

\section{Limitations of Student Observer/Consultant Programs}

First, it is obvious that students lack training and expertise in teaching. However, they do have current and extensive classroom experience. They may even be thought of as "experts" on learning at least their own. Instructors are aware of student observers' limitations and, when necessary, will take their comments with the appropriate reservations. 
Second, all three colleges with observer/consultant programs reviewed in this article have homogeneous, traditional-aged student bodies. And each faculty is much like its student body in race, religious background, geographical origins, and social class. This homogeneity has been shown to help students learn from their instructors (Fink, 1984) and presumably would be an asset in teacher-observer relationships, too. However, we do not know if student observer/consultant programs would be successful in more diverse colleges where students are more different from each other and from their instructors.

Third, there are some problems with the program despite the overwhelmingly positive responses. Comments from the faculty participant evaluations revealed that "reports were late in coming; they would have been more help earlier in the semester" (Sorenson, 1993b) and that the "teacher and [observer] need more contact" (Sorenson, 1993b). In the student participants' evaluations, students commented, 'two class visits were not enough for me to 'get a feel' for the instructor's teaching style," and "we should have gotten together sooner after the observation; by the time we met we had both forgotten quite a bit of the 'feel' of the class" (Sorenson, 1993b).

\section{How Student Observer Programs Fit with Other Classroom Data Gathering Techniques}

We who are charged with helping faculty members improve their teaching welcome opportunities to enable colleagues to examine their teaching with the goal of enhancing their students' learning. We welcome data gathering and any impetus which causes instructors to reflect on and discuss their teaching. In this article, we have added the student observer/consultant program to the following long list of means of gathering data about teaching and student learning:
a) student performance (projects, exams, etc.),
b) student evaluations of teachers (institutionally-designed or pro- prietary),
c) audio and video taping,
d) Classroom Assessment Techniques (Angelo \& Cross, 1993),
e) peer or consultant observation. 
Each type of evaluation can assess some measure of teaching and learning, depending on purpose, reliability, and validity. All of them provide views of instructors' teaching. Whether viewed together or singly, they provide a focus for discussion with faculty members about teaching and learning enhancement.

\section{A Mosaic of Our Teaching}

If we think of each of these methods as a piece of tile, we can use them to create a "mosaic of our teaching" and its attendant student learning. While the mosaic is not actually our teaching per se, any more than a mosaic of a mountain is actually a mountain, the mosaic can give us a good idea of our teaching, or the ridges and crevices of a mountain. Using a number of measurements helps instructors gain a clearer view of their teaching (and their students' learning) than using any one of them exclusively. Alone, each is but one tile, one bit of colored glass or datum; together they become an intricate mosaic, full of subtleties, revealing new perspectives with the changing light and the addition of new tiles.

Student observer data is one piece of this mosaic. Extending Zahorski's suggestions, we can value the student voice by inviting student observers to place tiles in the mosaic of our teaching, thereby enabling faculty members to see their mosaic in a new light. As meaningful new kinds of teacher-student relationships develop, student observer/consultant programs widen the circle of empowered participation in our academic community.

\section{References}

Angelo, T. A., \& Cross, K. P. (1993). Classroom assessment techniques: A handbook for college teachers (2nd ed.). San Francisco: Jossey-Bass.

Fink, L. D. (1973). Monitoring: A Method of Diagnostic Course Evaluation. Journal of Geography, 72(5), 16-20.

Fink, L. D. (1984). Situational factors affecting teaching. In Kenneth E. Eble, Ed., First year of college teaching. New directions for teaching and learning, No. 17. San Francisco: Jossey-Bass.

Guidelines for student observers in working with faculty. (1992). (Available from [Carleton College, Learning and Teaching Center, One North College Street, Northfield, MN 55057, (507) 663-5601]) 
Helling, B. (1988, Spring). A philosophy and a program for the observation of teaching. Faculty Development, p. 3.

Rhem, J. (Ed.). (1993). Paying students to observe teaching. The National Teaching \& Learning Forum, 3(2), 4-6. (Available from [ERIC Clearinghouse on Higher Education, One Dupont Circle, Suite 630, Washington, D.C. 20036-1183])

Rost, A. (1991, March 15). Student observers provide feedback for faculty members. Manitou Messenger, p. 2. (Available from [B. Helling, Teaching and Learning Center, St. Olaf College, Northfield, MN 55057])

Scafe, J. (1993, June). Student Observer Program: End-of-the-Year Report. (Available from [Carleton College, Learning and Teaching Center, One North College Street, Northfield, MN 55057, (507) 663-5601])

Sorenson, D. L. (1993a, October). [Unpublished interview with Barbara Helling].

Sorenson, D. L. (1993b). [BYU classroom student observer program evaluations]. Unpublished raw data.

Sorenson, D. L. (1994a). Classroom student observer program: Faculty handbook. (Available from [BYU Faculty Center, 167 HGB, Provo, UT 84602-2710])

Zahorski, K. J. (1993, October 16). Involving students in faculty development: A matter of value and values. Paper presented at the 18th Annual Conference of the Professional and Organizational Development Network in Higher Education, Rochester, MN.

\section{Resources}

Instructional developers interested in considering the implementation of a student observer/consultant program may find inspiration in the following readings:

Helling, B., \& Kuhlmann, D. (1988). Faculty visitor program: Helping teachers see themselves. In K. Lewis, \& J. Povlacs (Eds.), Face to face (pp. 103-119). Stillwater, OK: New Forums Press.

Palmer, P. J. (1983). To know as we are known: A spirituality of education. San Francisco: Harper.

Sorenson, D. L. (1994b). Classroom student observer program: Student observer handbook. (Available from [BYU Faculty Center, 167 HGB, Provo, UT 84602-2710])

BYU student observers receive the following list of suggested outside readings:

Angelo, T. A. (1993). A 'teacher's dozen.” T. J. Marchese, (Ed.), AAHE Bulletin, 45(8).

Bell, E. (1993, Fall). Sightings from my rearview mirror: Reflections on thirty years of teaching. Focus on Faculty. (Available from [BYU Faculty Center, 167 HGB, Provo, UT 84602]) 
Fink, L. D. (1994). Instructional consulting: A guide for developing professional knowledge. Manuscript submitted for publication.

Harb, J. N., Hurt, P. K., Terry, R. E., \& Williamson, K. J. (1991). Teaching through the cycle. Provo, UT: Brigham Young University.

Light, J. R. (1990, 1992). The Harvard Assessment Seminars, 1st \& 2nd Reports. Cambridge, MA: Harvard University.

Wingspread: The Johnson Foundation Inc. (1989). Seven Principles for Improving Teaching Effectiveness. Racine, WI. (Copies available from [Seven Principles Resource Center, P.O. Box 5838, Winona State University, Winona, MN 55987-5838, (507) 457-5020]) 